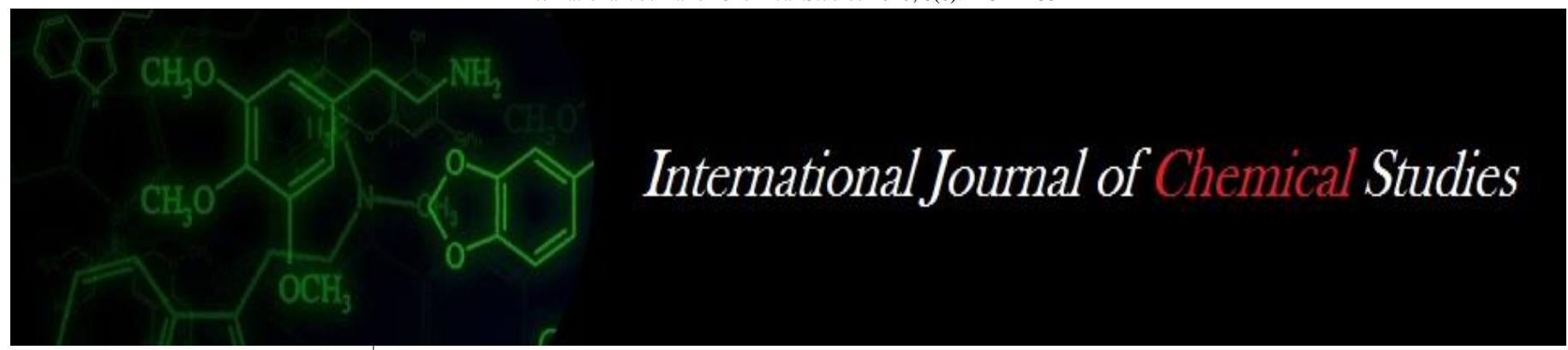

P-ISSN: 2349-8528

E-ISSN: 2321-4902

www.chemijournal.com

IJCS 2020; 8(6): 2231-2235

(C) 2020 IJCS

Received: 18-09-2020

Accepted: 19-10-2020

\section{Deekshitha DKD}

Department of Soil Science and

Agricultural Chemistry,

Agricultural College, Bapatla,

Andhra Pradesh, India

\section{Sujani Rao}

Department of Soil Science and

Agricultural Chemistry,

Agricultural College, Bapatla,

Andhra Pradesh, India

\section{Subbaiah PV}

Department of Soil Science and Agricultural Chemistry,

Agricultural College, Bapatla,

Andhra Pradesh, India

\section{Martin Luther M}

Department of Soil Science and Agricultural Chemistry,

Agricultural College, Bapatla,

Andhra Pradesh, India

\section{Srinivasa Rao V}

Department of Soil Science and Agricultural Chemistry,

Agricultural College, Bapatla,

Andhra Pradesh, India

\section{Direct and residual effect of integrated nitrogen management on available macro nutrient status of soil under rice-maize cropping system}

\author{
Deekshitha DKD, Sujani Rao Ch, Subbaiah PV, Martin Luther M and \\ Srinivasa Rao V
}

DOI: $\underline{\text { htps://doi.org/10.22271/chemi.2020.v8.i6af.11106 }}$

\begin{abstract}
A field experiment was conducted at Agricultural college farm, Bapatla during 2018-19 and 2019-20 to find out the direct and residual effect of integrated nitrogen management on available nutrients under rice - maize cropping system in sandy clay loam soil. The results revealed an improvement in available N, $\mathrm{P}_{2} \mathrm{O}_{5}, \mathrm{~K}_{2} \mathrm{O}$ with combined application of organics and inorganics over complete organic and control treatments.Application of $100 \% \mathrm{RDF}$ recorded higher soil available $\mathrm{N}, \mathrm{P}_{2} \mathrm{O}_{5}$ and $\mathrm{K}_{2} \mathrm{O}$ and it was on par with the treatments which received 50\% $\mathrm{N}$ through inorganics $+50 \% \mathrm{~N}$ through vermicompost or GLM respectively. Available $\mathrm{N}$ and $\mathrm{P}_{2} \mathrm{O}_{5}$ have shown significant difference with application of different nitrogen management treatments in kharif and different fertilizer doses in rabi. Available potassium was not significantly influenced by different treatments applied in kharif but significant differences were observed with application of different levels of N, P, K in rabi.
\end{abstract}

Keywords: soil under rice-maize cropping system field experiment

\section{Introduction}

In India rice-maize cropping system assumes prime importance under irrigated conditions. In Andhra Pradesh, rice is grown in an area of 2.16 million ha with annual production of 7.49 million tones and productivity of $3466 \mathrm{~kg} \mathrm{ha}^{-1}$ and maize is grown in an area of 0.23 million ha with annual production of 1.41 million tonnes and productivity of $6069 \mathrm{~kg} \mathrm{ha}^{-1}$ (Agricultural statistics at a glance 2016) ${ }^{[1]}$. However, the cultivation of two cereal crops like rice and maize in quick succession on the same piece of land is not advisable with respect to soil health, resulting in decline in the yield of both the crops. The continuous nutrient depletion from the agricultural fields is a severe threat to the soil health (Chand, 2010) ${ }^{[3]}$. Nutrient imbalance in soil results in low fertilizer use efficiency, low yields and low profits (Tiwari, 2002) ${ }^{[18]}$. In the light of above context, thisexperiment was planned to generate more information on contribution of nutrient management practices for rice and residual effect of these organics on maize in rice fallows during rabi season

\section{Materials and methods}

An experiment was conducted at Agricultural College Farm, Bapatla situated at $15^{\circ} 54^{\prime} \mathrm{N}$ latitude and $80^{\circ} 25^{\prime} \mathrm{E}$ longitude, at an altitude of $5.49 \mathrm{~m}$ above the mean sea level and is about $8 \mathrm{~km}$ away from the Bay of Bengal. The soil was sandy clay loam in texture. The initial soil analysis revealed that the soil is slightly alkaline in reaction, low in electrical conductivity, low in OC $(0.44 \%)$ low in available $\mathrm{N}(153.2$ $\left.\mathrm{kg} \mathrm{ha}^{-1}\right)$, medium in $\mathrm{P}_{2} \mathrm{O}_{5}\left(36.7 \mathrm{~kg} \mathrm{ha}^{-1}\right)$ and rich in $\mathrm{K}_{2} \mathrm{O}\left(341 \mathrm{~kg} \mathrm{ha}^{-1}\right)$. The experiment was carried out in the same field during both the years. The experiment was laid out in a randomized block design during kharif with nine treatments and replicated thrice. The treatments for kharif-Paddy are $\mathrm{T}_{1}$ : Control, $\mathrm{T}_{2}$ : 100 per cent RDF through Inorganic fertilizers, $\mathrm{T}_{3}: 100 \%$ Organic (Beejamrutham + Jeevamrutham), $\mathrm{T}_{4}$ : $100 \%$ Organic (Beejamrutham and Jeevamrutham) $+25 \%$ RDN through inorganicfertilizers, $\mathrm{T}_{5}: 75 \%$ RDN through Green leaf manure+ $25 \%$ RDN through inorganic fertilizers, $\mathrm{T}_{6}: 75 \%$ RDN through vermicompost $+25 \%$ RDN through inorganic fertilizers, $\mathrm{T}_{7}$ : 100\% Organic (Beejamrutham and Jeevamrutham $)+50 \%$ RDN through inorganicfertilizers, $\mathrm{T}_{8}: 50 \% \mathrm{RDN}$ through Green leaf manure+ $50 \%$ RDN through inorganic fertilizers, $\mathrm{T}_{9}: 50 \%$ RDN through vermicompost $+50 \%$ RDN through inorganic fertilizers. During rabi each plot was divided into two subplots viz., $100 \%$ RDF and 50\% RDF during both the years of study. Organic manures viz., Greenleaf manure, vermicompost were applied as per the treatments fifteen days before sowing.
Corresponding Author: Deekshitha DKD

Department of Soil Science and Agricultural Chemistry, Agricultural College, Bapatla, Andhra Pradesh, India 
The inorganic nitrogen $\left(120 \mathrm{~kg} \mathrm{~N} \mathrm{ha}^{-1}\right)$ was applied through urea. Phosphorous $\left(60 \mathrm{~kg} \mathrm{P}_{2} \mathrm{O}_{5} \mathrm{ha}^{-1}\right)$ and potassium $\left(40 \mathrm{~kg} \mathrm{~K}_{2} \mathrm{O} \mathrm{ha}^{-1}\right)$ were applied uniformly through single superphosphate and muriate of potash, respectively in all the treatments except $T_{3}$ and $T_{1}$ after considering their contents in GLM and vermicompost. Entire quantity of phosphorus and potassium and one third of the $\mathrm{N}$ were applied as basal at the time of sowing. Remaining inorganic $\mathrm{N}$ was applied in two equal splits at active tillering stage and panicle initiation stages.

In order to analyze the influence of soil properties on agronomic performance and to assess the impact of integrated nitrogen management on soil fertility, representative soil samples were taken from experimental plot and initial soil status was assessed. Rest all the soil samples were taken at different stages of rice and maize crops. Samples were taken from the cultivated soil layer (upper 15 $\mathrm{cm}$ ), using a single auger. The samples were air-dried, crushed, and gravel and other particles of size more size than $2 \mathrm{~mm}$ were removed with a sieve. Soil samples were drawn from individual plots from all the replications and analysed for available $\mathrm{N}, \mathrm{P}_{2} \mathrm{O}_{5}$ and $\mathrm{K}_{2} \mathrm{O}$ by following standard procedures. Statistical analysis of the experimental data was carried out as per the methods suggested by Gomez and Gomez (1984) ${ }^{[6]}$.

\section{Results and Discussion \\ Direct effect of INM on soil available nutrients under Rice Available Nitrogen}

The Results of the investigation showed that the use of organics, inorganics and their combination significantly influenced the available $\mathrm{N}$ status of soil at different growth stages and the results were furnished in the table 1 . In kharif, highest available nitrogen (208.43, 187.87, 161.54 and 214.64, 192.31, $164.92 \mathrm{~kg} \mathrm{ha}^{-1}$ in 2018 and 2019 respectively) in soil was recorded in treatment $T_{2}$ i.e., $100 \%$ RDF during active tillering, panicle initiation and harvest stages of paddy crop and however it was on par with the treatments which received combined application of 50\% RDN through inorganics + $50 \% \mathrm{~N}$ through vermicompost $\left(\mathrm{M}_{9}\right), 50 \% \mathrm{RDN}$ through inorganics + $50 \% \mathrm{~N}$ through Green leaf manure $\left(\mathrm{M}_{8}\right)$ and $50 \% \mathrm{RDN}$ through inorganics + Beejamrutham + Jeevamrutham $\left(\mathrm{M}_{7}\right)$.

This may be attributed to $\mathrm{N}$ mineralization from organic sources or by retaining $\mathrm{N}$ in labile microbial pool with the changing microbial flush. The most soil conditions might have helped the mineralization of soil $\mathrm{N}$ and greater multiplication of soil microbes, which could convert organically bound nitrogen into readily available form leading to building up of higher available N. Incorporation of organic manures in rice-maize system increased the nutrient pool and reduced the losses of nutrients. Vermicompost, which has comparatively narrow $\mathrm{C}$ : $\mathrm{N}$ ratio release nitrogen on decomposition steadily into the soil pool to meet the crop requirement. The results were in consonance with the findings of Kumar and Singh (2010) ${ }^{[13]}$ who reported significant increase in available nitrogen with application of organics along with inorganics.

The lowest available nitrogen in kharif-Paddy was recorded in treatment $\mathrm{M}_{1}$ which was control $\left(145.17,138.67,132.33 \mathrm{~kg} \mathrm{ha}^{-1}\right.$ in 2018 and 151.6, 143.14, $133.42 \mathrm{~kg} \mathrm{ha}^{-1}$ in 2019 at all the three stages) and it was on par with $100 \%$ organic (Beejamrutham + Jeevamrutham) during both the years of experimentation.

\section{Available Phosphorus}

In kharif, among all the treatments application of $100 \%$ RDF through inorganics to paddy $\left(\mathrm{M}_{2}\right)$ recorded highest available- $\mathrm{P}_{2} \mathrm{O}_{5}$ (54.33. $47.5,40.28 \mathrm{~kg} \mathrm{ha}^{-1}$ in 2018 and 56.24, 49.21, $41.34 \mathrm{~kg} \mathrm{ha}^{-1}$ in 2019 at all the three) (Table 2)however it was on par with treatments which received combined application of 50\% RDN through inrganics + $50 \%$ RDN through vermicompost $\left(\mathrm{M}_{9}\right), 50 \%$ RDN through inorganics $+50 \%$ RDN through Green leaf manure $\left(\mathrm{M}_{8}\right), 50 \% \mathrm{RDN}$ through inorganics $+100 \%$ organic (Beejamrutham + jeevamrutham) $\left(\mathrm{M}_{7}\right)$ at all the three stages and during both the years of study.

The results were in conformity with the findings of Lakshminarayana and Patiram (2006) ${ }^{[14]}$, Subehia et al., $2005^{[17]}$ who attributed the increase in available $\mathrm{P}_{2} \mathrm{O}_{5}$ content of soil to organic manures, which enhanced the labile pool of $\mathrm{P}$ in soil by complexing with Calcium, Magnesium and Alluminium in soil. Further chelation of organic acids with iron and alluminium reduced P-fixation and thereby improving the Phosphorus availability in soil (Boateng et al., 2006) ${ }^{[2]}$. The maximum available $\mathrm{P}$ was recorded in treatments which received vermicompost that might be due to the mobilization of soil $\mathrm{P}$ by the acidification of soil and the release of enzymes such as phosphatases and phytases of carboxylates such as gluconates and oxalates (Jones and Oburger, 2011) ${ }^{[11]}$. Similar results were observed by Hossain et al. (2010) ${ }^{[7]}$ and Jemila et al. (2017) ${ }^{[10]}$.

The lowest available-P was recorded in treatment $\mathrm{M}_{1}$ i.e., control $\left(34.22,32.83,32\right.$ and $36.48,33.6,32.36 \mathrm{~kg} \mathrm{ha}^{-1}$ during 2018 and 2019 respectively)at tillering, panicle initiation, harvest stages.

\section{Available-Potassium}

The results pertaining to available potassium were presented in table 3 . The data indicated that different nitrogen management treatments have not shown significant influence on soil available potassium at all the stages of crop growth in kharif during both the years of study. In kharif season, available potassium ranged from 337 to $398 \mathrm{~kg} \mathrm{ha}^{-1}$ and 338.4 to $432.47 \mathrm{~kg} \mathrm{ha}^{-1} ; 335$ to $371 \mathrm{~kg} \mathrm{ha}^{-1}$ and 337.8 to $373.6 \mathrm{~kg}$ $\mathrm{ha}^{-1} ; 332$ to $348 \mathrm{~kg} \mathrm{ha}^{-1}$ and 333.6 to $349.4 \mathrm{~kg} \mathrm{ha}^{-1}$ in active tillering, panicle initiation and harvest stages during 2018 and 2019 respectively.

\section{Residual effect of organics applied to rice on soil macro nutrient status under maize}

In rabi, among the main plots, the treatment $\mathrm{M}_{5}$ which received $75 \%$ $\mathrm{N}$ through Green leaf manure $+25 \%$ through inorganics during kharif recorded highest soil available nitrogen (Table 4 \& 5) (204.7, 197.2, 192.3 and 210.5, 203.1, $198.1 \mathrm{~kg} \mathrm{ha}^{-1}$ in 2019 and 2020 respectively) at kneehigh, tasseling and harvest stages of maize and it was on par with treatments $\mathbf{M}_{6}, \mathbf{M}_{8}, \mathrm{M}_{9}$ and $\mathbf{M}_{2}$. It implies the better residual effect of Green leaf manure when compared to vermicompost and (Beejamrutham+ Jeevamrutham). The presence of persistant material in Green leaf manure and vermicompost requires more time for decomposition, hence about 25 to $33 \%$ of $\mathrm{N}$ and small fraction of phosphorus and potassium in organic matter may be available to immediate crop and rest to subsequent crops (Inoko, $1984)^{[8]}$.

The results also showed that among the subplots, the plots which received $100 \% \operatorname{RDF}\left(S_{2}\right)$ recorded significantly higher available nitrogen when compared to subplots receiving $50 \% \mathrm{RDF}\left(\mathrm{S}_{1}\right)$. This might be attributed to the fact that with higher fertilizer dose, higher amount of fertilizer $\mathrm{N}$ could be converted into available form by the biochemical reaction of fertilizer $\mathrm{N}$ with soil organic matter (Kamla et al., 2005) [12]. The above results were also corroborated with Gadhiya et al. (2009) ${ }^{[5]}$ and Jat and Nanwal (2013) ${ }^{[9]}$.

\section{Available Phosphorus}

Data presented in table $6 \& 7$ revealed that during rabi, Organics applied to kharif rice have shown significant residual effect on soil available- $\mathrm{P}_{2} \mathrm{O}_{5}$ under maize and significantly highest available- $\mathrm{P}_{2} \mathrm{O}_{5}$ (55.3, 47.4, 42.2 kg ha-1 in 2019 and 58.4, 52.6, $49.8 \mathrm{~kg} \mathrm{ha}^{-1}$ in 2020) at knee high, tasseling and harvest stages was recorded in treatment $\mathrm{M}_{5}(75 \% \mathrm{~N}$ through Green leaf manure $+25 \% \mathrm{~N}$ through inorganics) and it was on par with all other INM treatments except $\mathrm{M}_{7}$ and $\mathrm{M}_{4}$ which received $100 \%$ organics along with $50 \%$ and $25 \% \mathrm{~N}$ through inorganics at all stages of crop growth. Mahala et al. (2006) ${ }^{[15]}$ also noticed the positive residual significant effect of organics on succeeding crop in terms of the available phosphorus in soil.

Lowest available-P at all the stages of maize crop was recorded in treatment $\mathrm{M}_{1}$ which is Control in previous season $(42.7,37.6$ and $36.1 \mathrm{~kg} \mathrm{ha}^{-1}$ during 2019 and 45.0, 40.0and $37.9 \mathrm{~kg} \mathrm{ha}^{-1}$ during 2020).

Irrespective of the Nitrogen management treatments in kharif, application of $100 \%$ RDF in rabi recorded significantly higher available- $\mathrm{P}_{2} \mathrm{O}_{5}$ at all stages of maize and during both the years of experimentation when compared to $50 \% \mathrm{RDF}$.

\section{Available Potassium}

In rabi no significant difference is observed among the main plots (table 8 \& 9) however application of Green leaf manure and Vermicompost along with inorganics to preceding rice have improved the available $\mathrm{K}_{2} \mathrm{O}$ content in soil under maize when compared to all other treatments. The beneficial effect of green leaf manuring and vermicompost on available potassium might be due to reduction of potassium fixation, solubilisation and release due to the interaction of organic matter with clay besides the direct potassium 
addition to the potassium pool of soil. Similar results were also observed by Sarkar et al. (2014) ${ }^{[16]}$ and Chettri et al. (2017) ${ }^{[4]}$.

Irrespective of the nitrogen management practices followed in preceding rice crop, the status of available $\mathrm{K}_{2} \mathrm{O}$ in soil under maize significantly increased with increase in level of fertilizer from $50 \%$ to $100 \%$ RDF during both the years of study at all the stages of crop growth. Interaction effect was found to be statistically insignificant.

Table 1: Effect of integrated use of inorganic fertilizers, organic manures on available nitrogen $\left(\mathrm{Kg} \mathrm{ha}^{-1}\right)$ in soil at different stages of rice

\begin{tabular}{|c|c|c|c|c|c|c|}
\hline \multirow[b]{2}{*}{ Treatments } & \multicolumn{3}{|c|}{ Kharif (2018) } & \multicolumn{3}{|c|}{ Kharif (2019) } \\
\hline & Tillering & \begin{tabular}{|c|} 
Panicle \\
Initiation
\end{tabular} & Harvest & Tillering & \begin{tabular}{|c|} 
Panicle \\
Initiation
\end{tabular} & Harvest \\
\hline $\mathrm{T}_{1}$ Control & 145.17 & 138.67 & 132.33 & 151.6 & 143.1 & 133.4 \\
\hline $\mathrm{T}_{2} 100 \% \mathrm{RDF}$ & 208.43 & 187.87 & 161.54 & 214.6 & 192.3 & 164.9 \\
\hline $\mathrm{T}_{3} 100 \%$ Organic (Beejamrutham + Jeevamrutham) & 152.43 & 145.76 & 136.64 & 158.3 & 148.8 & 139.8 \\
\hline $\mathrm{T}_{4} 100 \%$ Organic (Beejamrutham and Jeevamrutham) + 25\% RDN through inorganic fertilizers & 163.86 & 151.64 & 140.72 & 167.1 & 156.4 & 142.3 \\
\hline $\mathrm{T}_{5} 75 \%$ RDN through Green leaf manure+ $25 \%$ RDN through inorganic fertilizers & 176.34 & 160.12 & 148.76 & 178.6 & 163.2 & 151.1 \\
\hline $\mathrm{T}_{6} 75 \%$ RDN through vermicompost $+25 \%$ RDN through inorganic fertilizers & 179.32 & 161.38 & 149.62 & 183.5 & 164.3 & 152.2 \\
\hline $\mathrm{T}_{7} 100 \%$ Organic (Beejamrutham and Jeevamrutham) 50\% RDN through inorganic fertilizers & 182.00 & 163.52 & 151.24 & 187.9 & 167.1 & 154.9 \\
\hline $\mathrm{T}_{8} 50 \%$ RDN through Green leaf manure+ $50 \%$ RDN through inorganic fertilizers & 193.24 & 179.28 & 156.84 & 197.6 & 183.1 & 159.3 \\
\hline $\mathrm{T}_{9} 50 \%$ RDN through vermicompost $+50 \%$ RDN through inorganic fertilizers & 198.56 & 182.64 & 158.22 & 202.8 & 186.2 & 161.4 \\
\hline $\mathrm{SEm} \pm$ & 5.5 & 4.28 & 3.52 & 5.92 & 4.36 & 4.05 \\
\hline CD@0.05 & 14.84 & 11.68 & 9.49 & 15.76 & 12.54 & 10.68 \\
\hline $\mathrm{CV}(\%)$ & 7.56 & 8.78 & 8.14 & 9.09 & 8.71 & 8.56 \\
\hline
\end{tabular}

Table 2: Effect of integrated use of inorganic fertilizers, organic manures on available phosphorus $\left(\mathrm{Kg}^{-1}\right)$ in soil at different stages of rice

\begin{tabular}{|c|c|c|c|c|c|c|}
\hline \multirow[b]{2}{*}{ Treatments } & \multicolumn{3}{|c|}{ Kharif (2018) } & \multicolumn{3}{|c|}{ Kharif (2019) } \\
\hline & Tillering & $\begin{array}{c}\text { Panicle } \\
\text { Initiation }\end{array}$ & Harvest & Tillering & $\begin{array}{c}\text { Panicle } \\
\text { Initiation }\end{array}$ & Harvest \\
\hline $\mathrm{T}_{1}$ Control & 34.22 & 32.83 & 32.00 & 36.48 & 33.62 & 32.36 \\
\hline $\mathrm{T}_{2} 100 \% \mathrm{RDF}$ & 54.33 & 47.50 & 40.28 & 56.24 & 49.21 & 41.34 \\
\hline $\mathrm{T}_{3} 100 \%$ Organic (Beejamrutham + Jeevamrutham) & 39.25 & 35.20 & 34.18 & 41.04 & 37.28 & 36.68 \\
\hline $\mathrm{T}_{4} 100 \%$ Organic (Beejamrutham and Jeevamrutham) + 25\% RDN through inorganic fertilizers & 48.94 & 43.26 & 37.46 & 50.58 & 44.86 & 38.94 \\
\hline $\mathrm{T}_{5} 75 \%$ RDN through Green leaf manure+ $25 \%$ RDN through inorganic fertilizers & 44.66 & 39.43 & 36.34 & 47.26 & 41.72 & 37.16 \\
\hline $\mathrm{T}_{6} 75 \% \mathrm{RDN}$ through vermicompost $+25 \% \mathrm{RDN}$ through inorganic fertilizers & 46.34 & 40.78 & 37.82 & 48.88 & 43.12 & 38.62 \\
\hline $\mathrm{T}_{7} 100 \%$ Organic (Beejamrutham and Jeevamrutham) 50\% RDN through inorganic fertilizers & 50.14 & 44.67 & 38.74 & 52.32 & 45.72 & 39.96 \\
\hline $\mathrm{T}_{8} 50 \%$ RDN through Green leaf manure+ 50\% RDN through inorganic fertilizers & 49.40 & 43.44 & 38.32 & 51.24 & 45.14 & 39.38 \\
\hline $\mathrm{T}_{9} 50 \%$ RDN through vermicompost $+50 \%$ RDN through inorganic fertilizers & 51.72 & 45.20 & 39.46 & 53.86 & 46.48 & 41.24 \\
\hline SEm \pm & 1.76 & 1.50 & 1.28 & 1.71 & 1.70 & 1.40 \\
\hline CD@0.05 & 5.27 & 4.06 & 3.60 & 5.12 & 4.20 & 3.8 \\
\hline $\mathrm{CV}(\%)$ & 6.50 & 6.22 & 6.06 & 6.05 & 6.84 & 6.28 \\
\hline
\end{tabular}

Table 3: Effect of integrated use of inorganic fertilizers, organic manures on available potassium $\left(\mathrm{kg} \mathrm{ha}^{-1}\right)$ in soil at different stages of rice

\begin{tabular}{|c|c|c|c|c|c|c|}
\hline \multirow[b]{2}{*}{ Treatments } & \multicolumn{3}{|c|}{ Kharif (2018) } & \multicolumn{3}{|c|}{ Kharif (2019) } \\
\hline & Tillering & $\begin{array}{c}\text { Panicle } \\
\text { Initiation }\end{array}$ & Harvest & Tillering & \begin{tabular}{c|} 
Panicle \\
Initiation
\end{tabular} & Harvest \\
\hline $\mathrm{T}_{1}$ Control & 337.00 & 335.00 & 332.00 & 338.40 & 337.80 & 333.60 \\
\hline $\mathrm{T}_{2} 100 \% \mathrm{RDF}$ & 398.00 & 371.00 & 348.00 & 432.47 & 373.60 & 349.40 \\
\hline $\mathrm{T}_{3} 100 \%$ Organic (Beejamrutham + Jeevamrutham) & 346.00 & 341.00 & 337.00 & 347.80 & 342.60 & 336.80 \\
\hline $\mathrm{T}_{4} 100 \%$ Organic (Beejamrutham and Jeevamrutham) $+25 \%$ RDN through inorganic fertilizers & 391.00 & 362.00 & 342.00 & 393.20 & 359.40 & 344.20 \\
\hline $\mathrm{T}_{5} 75 \%$ RDN through Green leaf manure+ $25 \% \mathrm{RDN}$ through inorganic fertilizers & 365.00 & 349.00 & 339.00 & 368.80 & 351.70 & 341.30 \\
\hline $\mathrm{T}_{6} 75 \% \mathrm{RDN}$ through vermicompost $+25 \% \mathrm{RDN}$ through inorganic fertilizers & 371.00 & 353.00 & 340.00 & 375.20 & 353.80 & 342.40 \\
\hline $\mathrm{T}_{7} 100 \%$ Organic (Beejamrutham and Jeevamrutham) 50\% RDN through inorganic fertilizers & 394.00 & 365.00 & 344.00 & 402.20 & 367.20 & 346.20 \\
\hline $\mathrm{T}_{8} 50 \% \mathrm{RDN}$ through Green leaf manure+ $50 \%$ RDN through inorganic fertilizers & 388.00 & 357.00 & 341.00 & 391.20 & 356.00 & 343.80 \\
\hline $\mathrm{T}_{9} 50 \%$ RDN through vermicompost $+50 \%$ RDN through inorganic fertilizers & 392.00 & 363.00 & 343.00 & 394.40 & 366.20 & 345.60 \\
\hline $\mathrm{SEm} \pm$ & 13.91 & 13.84 & 12.01 & 18.05 & 12.69 & 12.36 \\
\hline CD@0.05 & NS & NS & NS & NS & NS & NS \\
\hline $\mathrm{CV}(\%)$ & 6.41 & 6.75 & 6.15 & 8.17 & 6.17 & 6.25 \\
\hline
\end{tabular}

Table 4: Residual effect of organics applied to kharif paddy on available nitrogen ( $\left.\mathrm{kg} \mathrm{ha}^{-1}\right)$ in soil at different stages of maize (Rabi, 2019)

\begin{tabular}{|c|c|c|c|c|c|c|c|c|c|}
\hline & \multicolumn{2}{|c|}{ Knee High } & \multirow{2}{*}{ Mean } & \multicolumn{2}{|c|}{ Tasseling } & \multirow{2}{*}{ Mean } & \multicolumn{2}{|c|}{ Harvest } & \multirow{2}{*}{ Mean } \\
\hline & S1 & S2 & & S1 & S2 & & S1 & S2 & \\
\hline M1 & 149.2 & 187.2 & 168.2 & 142.7 & 182.6 & 162.7 & 136.2 & 178.0 & 157.1 \\
\hline M2 & 168.2 & 202.6 & 185.4 & 162.3 & 197.8 & 180.1 & 156.4 & 193.0 & 174.7 \\
\hline M3 & 152.3 & 191.5 & 171.9 & 145.9 & 187.0 & 166.5 & 139.5 & 182.5 & 161.0 \\
\hline M4 & 158.2 & 195.8 & 177.0 & 151.7 & 190.7 & 171.2 & 145.2 & 185.6 & 165.4 \\
\hline M5 & 184.5 & 224.8 & 204.7 & 179.1 & 215.3 & 197.2 & 173.7 & 210.8 & 192.3 \\
\hline M6 & 182.3 & 211.3 & 196.8 & 176.4 & 208.4 & 192.4 & 170.5 & 203.5 & 187.0 \\
\hline M7 & 166.7 & 198.7 & 182.7 & 160.4 & 193.3 & 176.9 & 154.1 & 187.9 & 171.0 \\
\hline M8 & 175.4 & 208.1 & 191.8 & 169.1 & 203.8 & 186.5 & 162.8 & 199.5 & 181.2 \\
\hline M9 & 169.5 & 204.2 & 186.9 & 163.2 & 199.8 & 181.5 & 156.9 & 195.4 & 176.2 \\
\hline \multirow[t]{2}{*}{ Mean } & 167.4 & 202.7 & & 161.2 & 197.6 & & 155.0 & 192.9 & \\
\hline & SEm \pm & $C D(p=0.05)$ & CV (\%) & SEm \pm & $\mathrm{CD}(\mathrm{p}=0.05)$ & CV (\%) & SEm \pm & $C D(p=0.05)$ & CV (\%) \\
\hline $\mathbf{M}$ & 6.62 & 19.86 & 8.8 & 7.12 & 21.35 & 9.7 & 6.99 & 20.95 & 9.8 \\
\hline $\mathbf{S}$ & 3.38 & 10.05 & 9.5 & 2.56 & 7.61 & 7.4 & 2.48 & 7.38 & 7.4 \\
\hline MX S & 9.77 & NS & & 8.96 & NS & & 8.75 & NS & \\
\hline SXM & 10.15 & NS & & 7.68 & NS & & 7.45 & NS & \\
\hline
\end{tabular}


Table 5: Residual effect of organics applied to kharif paddy on available nitrogen $\left(\mathrm{kg} \mathrm{ha}^{-1}\right)$ in soil at different stages of maize $($ Rabi, 2020)

\begin{tabular}{|c|c|c|c|c|c|c|c|c|c|}
\hline & \multicolumn{2}{|c|}{ Knee High } & \multirow{2}{*}{ Mean } & \multicolumn{2}{|c|}{ Tasseling } & \multirow{2}{*}{ Mean } & \multicolumn{2}{|c|}{ Harvest } & \multirow{2}{*}{ Mean } \\
\hline & S1 & S2 & & S1 & S2 & & S1 & S2 & \\
\hline M1 & 152.4 & 190.4 & 171.4 & 145.9 & 185.7 & 165.8 & 139.3 & 181.1 & 160.2 \\
\hline M2 & 173.3 & 207.7 & 190.5 & 167.4 & 202.9 & 185.2 & 161.5 & 198.1 & 179.8 \\
\hline M3 & 156.3 & 195.6 & 176.0 & 150.0 & 191.1 & 170.5 & 143.6 & 186.6 & 165.1 \\
\hline M4 & 162.2 & 199.9 & 181.1 & 155.8 & 194.8 & 175.3 & 149.3 & 189.7 & 169.5 \\
\hline M5 & 190.4 & 230.7 & 210.5 & 185.0 & 221.2 & 203.1 & 179.6 & 216.7 & 198.1 \\
\hline M6 & 188.2 & 217.2 & 202.7 & 182.3 & 214.3 & 198.3 & 176.4 & 209.4 & 192.9 \\
\hline M7 & 170.8 & 202.8 & 186.8 & 164.5 & 197.4 & 180.9 & 158.2 & 192.0 & 175.1 \\
\hline M8 & 181.3 & 214.0 & 197.6 & 175.0 & 209.7 & 192.3 & 168.7 & 205.4 & 187.0 \\
\hline M9 & 175.4 & 210.1 & 192.7 & 169.1 & 205.7 & 187.4 & 162.8 & 201.3 & 182.0 \\
\hline Mean & 172.3 & 207.6 & & 166.1 & 202.5 & & 159.9 & 197.8 & \\
\hline & SEm \pm & $\mathrm{CD}(\mathrm{p}=0.05)$ & CV (\%) & SEm \pm & $\mathrm{CD}(\mathrm{p}=\mathbf{0 . 0 5})$ & $\mathrm{CV}(\%)$ & SEm \pm & $\mathrm{CD}(\mathrm{p}=\mathbf{0 . 0 5})$ & CV $(\%)$ \\
\hline M & 6.62 & 19.86 & 8.5 & 7.12 & 21.35 & 9.5 & 6.99 & 20.95 & 9.6 \\
\hline $\mathbf{S}$ & 3.38 & 10.05 & 9.3 & 2.56 & 7.61 & 7.2 & 2.48 & 7.38 & 7.2 \\
\hline MXS & 9.77 & NS & & 8.96 & NS & & 8.75 & NS & \\
\hline SXM & 10.15 & NS & & 7.68 & NS & & 7.45 & NS & \\
\hline
\end{tabular}

Table 6: Residual effect of organics applied to kharif paddy on available phosphorus ( $\left.\mathrm{kg} \mathrm{ha}^{-1}\right)$ in soil at different stages of maize (Rabi, 2019)

\begin{tabular}{|c|c|c|c|c|c|c|c|c|c|}
\hline & \multicolumn{2}{|c|}{ Knee High } & \multirow{2}{*}{ Mean } & \multicolumn{2}{|c|}{ Tasseling } & \multirow{2}{*}{ Mean } & \multicolumn{2}{|c|}{ Harvest } & \multirow{2}{*}{ Mean } \\
\hline & S1 & S2 & & S1 & S2 & & S1 & S2 & \\
\hline M1 & 39.4 & 46.0 & 42.7 & 35.3 & 40.0 & 37.6 & 34.3 & 38.0 & 36.1 \\
\hline M2 & 47.3 & 55.3 & 51.3 & 41.4 & 46.8 & 44.1 & 36.4 & 41.5 & 39.0 \\
\hline M3 & 41.2 & 47.9 & 44.6 & 37.4 & 40.9 & 39.2 & 36.2 & 38.5 & 37.4 \\
\hline M4 & 44.5 & 50.8 & 47.6 & 39.6 & 45.4 & 42.5 & 35.2 & 41.1 & 38.2 \\
\hline M5 & 50.8 & 59.8 & 55.3 & 44.3 & 50.5 & 47.4 & 40.1 & 44.3 & 42.2 \\
\hline M6 & 49.3 & 57.2 & 53.3 & 43.9 & 49.7 & 46.8 & 38.8 & 42.6 & 40.7 \\
\hline M7 & 45.7 & 51.7 & 48.7 & 40.6 & 46.3 & 43.5 & 35.8 & 40.7 & 38.3 \\
\hline M8 & 48.5 & 57.3 & 52.9 & 42.3 & 48.9 & 45.6 & 37.0 & 43.5 & 40.3 \\
\hline M9 & 47.9 & 56.2 & 52.1 & 41.0 & 48.8 & 44.9 & 37.8 & 42.3 & 40.0 \\
\hline Mean & 46.1 & 53.6 & & 40.7 & 46.4 & & 36.9 & 41.4 & \\
\hline & SEm \pm & $C D(p=0.05)$ & CV (\%) & SEm+ & CD $(p=0.05)$ & CV (\%) & SEm + & $\mathrm{CD}(\mathrm{p}=0.05)$ & $\mathrm{CV}(\%)$ \\
\hline $\mathbf{M}$ & 1.95 & 5.9 & 9.6 & 1.71 & 4.8 & 9.6 & 1.11 & 3 & 6.9 \\
\hline $\mathbf{S}$ & 0.94 & 3 & 9.8 & 0.76 & 2 & 9.1 & 0.80 & 2 & 10.6 \\
\hline MXS & 2.80 & NS & & 2.36 & NS & & 2.03 & NS & \\
\hline SXM & 2.83 & NS & & 2.29 & NS & & 2.40 & NS & \\
\hline
\end{tabular}

Table 7: Residual effect of organics applied to kharif paddy on available phosphorus $\left(\mathrm{kg} \mathrm{ha}^{-1}\right)$ in soil at different stages of maize (Rabi, 2020)

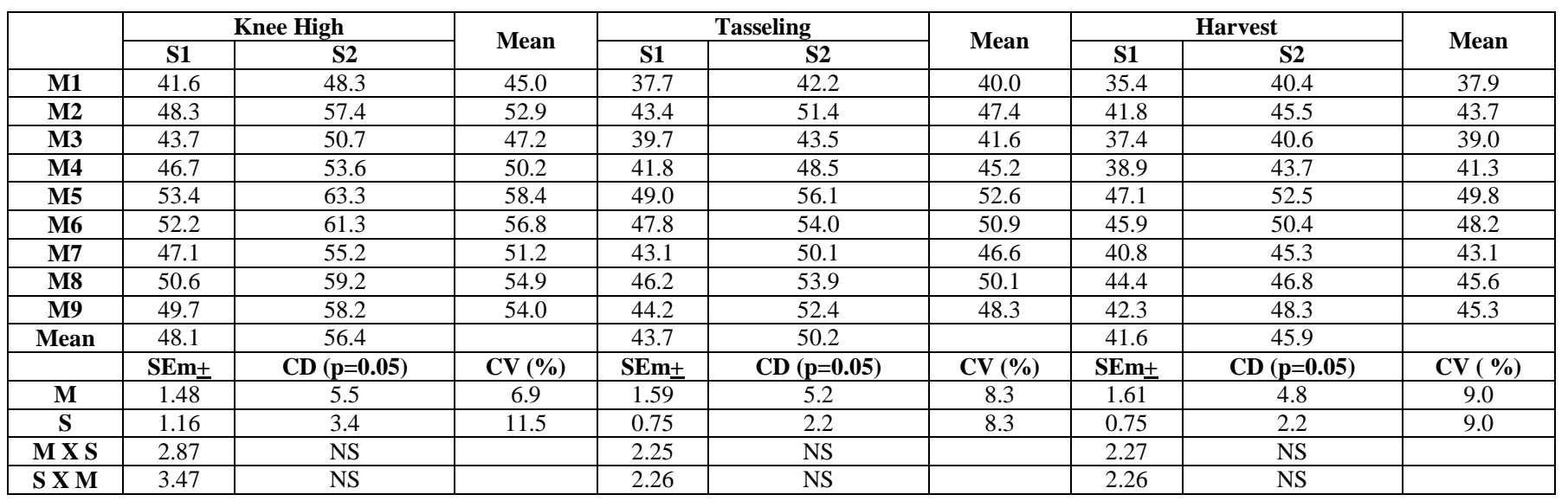

Table 8: Residual effect of organics applied to kharif paddy on available potassium ( $\left.\mathrm{kg} \mathrm{ha}^{-1}\right)$ in soil at different stages of maize (Rabi, 2019)

\begin{tabular}{|c|c|c|c|c|c|c|c|c|c|}
\hline & \multicolumn{2}{|c|}{ Knee High } & \multirow[b]{2}{*}{ Mean } & \multicolumn{2}{|c|}{ Tasseling } & \multirow[b]{2}{*}{ Mean } & \multicolumn{2}{|c|}{ Harvest } & \multirow[b]{2}{*}{ Mean } \\
\hline & S1 & S2 & & S1 & S2 & & S1 & S2 & \\
\hline M1 & 351.0 & 383.0 & 367.0 & 340.0 & 352.0 & 346.0 & 331.0 & 340.0 & 335.5 \\
\hline M2 & 364.0 & 401.0 & 382.5 & 351.0 & 368.0 & 359.5 & 341.0 & 356.0 & 348.5 \\
\hline M3 & 358.0 & 390.0 & 374.0 & 346.0 & 359.0 & 352.5 & 335.0 & 346.0 & 340.5 \\
\hline M4 & 361.0 & 396.0 & 378.5 & 348.0 & 365.0 & 356.5 & 339.0 & 351.0 & 345.0 \\
\hline M5 & 373.0 & 409.0 & 391.0 & 358.0 & 377.0 & 367.5 & 344.0 & 371.0 & 357.5 \\
\hline M6 & 371.0 & 404.0 & 387.5 & 354.0 & 373.0 & 363.5 & 349.0 & 364.0 & 356.5 \\
\hline M7 & 363.0 & 398.0 & 380.5 & 350.0 & 364.0 & 357.0 & 341.0 & 353.0 & 347.0 \\
\hline M8 & 367.0 & 404.0 & 385.5 & 355.0 & 371.0 & 363.0 & 345.0 & 359.0 & 352.0 \\
\hline M9 & 365.0 & 402.0 & 383.5 & 351.0 & 369.0 & 360 & 343.0 & 357.0 & 350.0 \\
\hline Mean & 363.7 & 398.6 & & 350.3 & 366.4 & & 340.9 & 355.2 & \\
\hline & SEm \pm & $\mathrm{CD}(\mathrm{p}=0.05)$ & CV (\%) & SEm \pm & $\mathrm{CD}(\mathrm{p}=\mathbf{0 . 0 5})$ & CV (\%) & $\mathrm{SEm}_{\underline{ \pm}}$ & $\mathrm{CD}(\mathrm{p}=0.05)$ & CV $(\%)$ \\
\hline $\mathbf{M}$ & 6.84 & NS & 6.0 & 8.78 & NS & 6.0 & 10.32 & NS & 7.3 \\
\hline $\mathbf{S}$ & 4.65 & 14 & 6.3 & 4.76 & 14 & 6.9 & 4.26 & 13 & 6.4 \\
\hline MXS & 12.00 & NS & & 13.38 & NS & & 13.71 & NS & \\
\hline S X M & 13.94 & NS & & 14.27 & $\mathrm{NS}$ & & 12.77 & NS & \\
\hline
\end{tabular}


Table 9: Residual effect of organics applied to kharif paddy on available potassium $\left(\mathrm{kg} \mathrm{ha}^{-1}\right)$ in soil at different stages of maize (Rabi, 2020)

\begin{tabular}{|c|c|c|c|c|c|c|c|c|c|}
\hline & \multicolumn{2}{|c|}{ Knee High } & \multirow{2}{*}{ Mean } & \multicolumn{2}{|c|}{ Tasseling } & \multirow{2}{*}{ Mean } & \multicolumn{2}{|c|}{ Harvest } & \multirow{2}{*}{ Mean } \\
\hline & S1 & S2 & & S1 & S2 & & S1 & $\mathbf{S 2}$ & \\
\hline M1 & 354.0 & 374.0 & 364.0 & 344.0 & 361.0 & 352.5 & 335.0 & 347.0 & 341.0 \\
\hline M2 & 367.4 & 394.3 & 380.9 & 353.0 & 373.0 & 363.0 & 346.0 & 359.0 & 352.5 \\
\hline M3 & 361.1 & 383.2 & 372.2 & 349.0 & 364.0 & 356.5 & 339.0 & 351.9 & 345.5 \\
\hline M4 & 364.9 & 388.1 & 376.5 & 351.0 & 368.0 & 359.5 & 343.0 & 356.0 & 349.5 \\
\hline M5 & 375.6 & 404.1 & 389.9 & 362.0 & 384.0 & 373.0 & 356.0 & 374.0 & 365.0 \\
\hline M6 & 374.6 & 402.1 & 388.4 & 358.0 & 381.0 & 369.5 & 352.0 & 369.0 & 360.5 \\
\hline M7 & 367.5 & 390.0 & 378.8 & 353.0 & 372.0 & 362.5 & 344.0 & 357.0 & 350.5 \\
\hline M8 & 371.6 & 397.1 & 384.4 & 356.0 & 379.0 & 367.5 & 349.0 & 363.0 & 356.0 \\
\hline M9 & 369.9 & 395.0 & 382.5 & 354.0 & 374.0 & 364.0 & 347.0 & 361.0 & 354.0 \\
\hline \multirow[t]{2}{*}{ Mean } & 367.4 & 392.0 & & 353.3 & 372.9 & & 345.7 & 359.8 & \\
\hline & SEm+ & $\mathrm{CD}(\mathrm{p}=0.05)$ & CV (\%) & SEm+ & $\mathrm{CD}(\mathrm{p}=0.05)$ & CV (\%) & SEm+ & $\mathrm{CD}(\mathrm{p}=0.05)$ & CV (\%) \\
\hline $\mathbf{M}$ & 10.62 & NS & 6.8 & 8.31 & NS & 6.6 & 9.14 & NS & 6.3 \\
\hline $\mathbf{S}$ & 4.78 & 14 & 6.5 & 4.18 & 12 & 6.0 & 4.58 & 14 & 6.7 \\
\hline MXS & 14.68 & NS & & 12.15 & NS & & 13.34 & NS & \\
\hline S X M & 14.34 & NS & & 12.55 & NS & & 13.74 & NS & \\
\hline
\end{tabular}

\section{Interaction}

Interaction between main plots and subplots was found nonsignificant in case of available $\mathrm{N}, \mathrm{P}_{2} \mathrm{O}_{5}$ and $\mathrm{K}_{2} \mathrm{O}$.

\section{Conclusions}

The results of the study revealed that application of $100 \%$ RDF through inorganic fertilizers recorded significantly highest available $\mathrm{N}, \mathrm{P}$ and $\mathrm{K}$ and it was on par treatments which received $50 \% \mathrm{~N}$ through vermicompost+ $50 \% \mathrm{~N}$ through inorganics and $50 \% \mathrm{~N}$ through GLM+50\% $\mathrm{N}$ through inorganics. Whereas application of $75 \% \mathrm{~N}$ through GLM+25\% N through inorganics to paddy in kharif resulted in highest soil available $\mathrm{N}, \mathrm{P}$ and $\mathrm{K}$ under maize at all the stages indicating its prominent residual effect.However Soil available $\mathrm{N}$ and $\mathrm{P}_{2} \mathrm{O}_{5}$ were significantly influenced by different nitrogen management treatment but available $\mathrm{K}_{2} \mathrm{O}$ was not significantly influenced by different treatments.

\section{References}

1. Agricultural statistics at a glance.Government of India, Ministry of Agriculture and farmers welfare. Department of Agriculture, cooperation and farmers welfare 2016.

2. Boateng SA, Zichermann J, KornahernsM.Poultry manure effect on growth and yield of maize.West Africa Journal of Applied Ecology2006;9:1-11.

3. Chand S.Challenges of soil quality of Indian soils vis-à-vis food security.Current Science 2010;99(3):278-280.

4. Chettri P, Maiti D, Rizal B.Studies on soil properties as affected by integrated nutrient management practice in different cultivars of local scented rice. Journal of Crop and Weed2017;13(2):25-29.

5. Gadhiya SS, Patel BB, Jadav NJ, Pavaya RP, Patel MV, Patel VR.Effect of different levels of nitrogen, phosphorus and potassium on growth and quality of $B t$ cotton.Asian Journal of Soil Science2009;4(1):37-42.

6. Gomez KA, GomezAA.Randomized Block Design in Statistical Procedure for Agricultural Research. Published by a Wiley Inter Science, USA 1984, 621-635.

7. Hossain AT, Rahman F, Saha PK,Solaiman ARM.Effects of different aged poultry litter on the yield and nutrient balance in boro rice cultivation.Bangladesh Journal of Agricultural Research2010;35(3):497-505.

8. Inoko A.Compost as sources of plant nutrients. In: organic matter and rice. IRRI, Los Banos, Philippines 1984, 137-145.

9. Jat RD, Nanwal RK. Growth, nutrient uptake and profitability of Bt cotton (Gossypium hirsutum L.)influenced by spacing and nutrient levels.Crop Research2013;45(1,2 \&3):248-252.

10. Jemila C, Bakiyathusaliha B, Udayakumar S.Evaluating the effect of phosphatic fertilizer on soil and plant $\mathrm{P}$ availability and maximizing rice crop yield. Oryza2017;54(3):305-313.

11. Jones DL, Oburger E.Solubilization of phosphorus by soil micro organisms In: EK Beunemann, A. Oberson, E. Froard, eds. Phosphorus in action. Springer, Newyork2011, 169-198.

12. Kamla K, Gupta CS,Paliyal SS.Effect of chemical fertilizers vis-à-vis organic manures (vermicompost, FYM) on wheat yield and soil health.Himachal Journal of Agricultural Research2005;31(2):48-51.
13. Kumar V, Singh AP.Long-term effect of green manuring and farm yard manure on yield and soil fertility status in rice-wheat cropping system. Journal of the Indian Society of Soil Science2010;58(4):409-412.

14. Laxminarayana K, Patiram.Effect of integrated use of inorganic, biological and organic manures on rice productivity \& soil fertility in Ultisols of Mizorm. Journal of the Indian Society of Soil Science2006;54:213-220.

15. Mahala HL, Shakawat MS,Shivram RK.Direct and residual effect of organic sources and levels of $\mathrm{P} \& \mathrm{~N}$ in maize mustard cropping sequence. Indian Journal of Agronomy2006;51(1):1013.

16. Sarkar S, Mandal M, Das DK.Effect of integrated application of green manure and biofertilisers on soil fertility in rice-pea cropping system.Environment and Ecology2014;32(3):10101015.

17. Subehia SK, Verma S, Sharma SP.Effect of long-term use of chemical fertilizers with and without organics on form of soil acidity, phopshorus adsorption and crop yields in an acid soil.Journal of theIndian Society of Soil Science2005;53(2):308-314.

18. Tiwari KN.Rice production and nutrient management in India.Better crop international2002;16:18-22. 